\title{
Political economy of prudent budgetary policy
}

\author{
Frederick van der Ploeg
}

Published online: 7 May 2009

(C) The Author(s) 2009. This article is published with open access at Springerlink.com

\begin{abstract}
The principles of tax smoothing and public debt management with stochastic shocks to future national income are extended for prudence. A prudent government deliberately underestimates future national income and the tax base, especially if the variance and persistence of shocks hitting the tax base are large and the tax rate is high. As a precaution the tax rate is thus set higher and public spending lower to build precautionary buffers. This leads to gradual reductions in debt and debt service over time and thus, depending on political preferences, cuts in taxes or increases in public spending. Prudence offsets the intertemporal spending, tax and debt biases resulting from common-pool distortions. Appointing a strong finance minister with as many voting rights as the spending ministers combined ensures that the intratemporal common-pool distortions of an excessively large public sector are eliminated. A strong and prudent minister of finance can thus offset the impatient profligacy of squabbling spending ministers. However, if voters care about outcomes on election eve, finance ministers are tempted to build excessive precautionary buffers early on to dish out tax cuts and boost spending on election eve. Too much prudence may thus be abused for short-run electoral gains.
\end{abstract}

Keywords Precautionary taxation and saving - Common pool · Electoral budget cycles

JEL Classification $\mathrm{H} 21 \cdot \mathrm{H} 60$

\footnotetext{
F. van der Ploeg $(\bowtie)$

Department of Economics, University of Oxford, Manor Road Building, Manor Road,

Oxford OX1 3UQ, UK

e-mail: rick.vanderploeg@economics.ox.ac.uk

F. van der Ploeg

Mlnt, University of Amsterdam, Roetersstraat 11, 1018 WB Amsterdam, The Netherlands
} 


\section{Introduction}

The reputation of a good minister of finance is based on prudence and caution. A good minister of finance will be forgiven if unexpected windfall revenues appear, but will be scorned if the budget turns out year after year worse than expected. Just as the electorate prefers to appoint an ultraconservative central banker (Rogoff 1985), the people appreciate a conservative minister of finance. While a central banker should be curbed to prevent reneging on previous announcements to keep the money supply in check, a minister of finance is under perennial pressure from spending ministers to relax budgetary discipline. Intuitively, it thus makes sense to appoint a prudent minister of finance. This insight inspired the practice in the Netherlands during 1994-2007 of deliberately underestimating future growth in national income by say a quarter or half percent in order to err on the safe side and not be surprised by unexpected worsening of the public finances. ${ }^{1}$ The main objective of this paper is to formalize this notion of prudent budgetary policy within the context of Barro's (1979) theory of tax smoothing and optimal debt management and to provide a political economy rationale for it. We realize it may have been better to use a more fully specified, less ad hoc model with proper micro foundations, but we believe the simplicity of this framework permits a clean analysis of both prudent policy making and of the game-theoretic interactions between the finance minister and the spending ministers.

The theory of precautionary saving developed for households (e.g., Sibley 1975; Zeldes 1989; Kimball 1990) can be applied to study the principles of prudent budgetary policy and the building of precautionary buffers by governments facing stochastic shocks about future levels of national income and the tax base. Our approach to deriving precautionary budgetary policy is to introduce prudence or temporal risk aversion into a standard intertemporal welfare loss criterion which trades off minimizing quadratic tax distortions against minimizing the distance of public spending from its bliss level and applies earlier work on household saving with prudence and temporal aversion (van der Ploeg 1993; Bommier and Rochet 2006; Bommier 2006). ${ }^{2}$ Prudence implies that the policy maker plays a min-max game against Nature. The policy maker hedges against undesirable outcomes by postulating that Nature deliberately chooses shocks to damage the objectives of the policy maker even though, from a purely statistical point of view, they do not hurt on average.

A key insight of our paper is that a prudent government deliberately underestimates future forecasts of national income and the tax base. As a precaution the tax rate is set higher and the level of public spending lower than without prudence and the government builds precautionary buffers. As a result, even though budgeted tax rates

\footnotetext{
${ }^{1}$ The new government of the Netherlands has in 2007 abandoned prudent forecasts of national income and tax bases. Instead, it claims to be prudent by pursuing a more ambitious target for the final financial surplus.

${ }^{2}$ The government thus minimizes an exponential transformation of the quadratic intertemporal welfare loss function. Given a linear model with additive normally distributed errors, the optimal policy rules are linear with reaction coefficients that depend on the variances and covariances of the stochastic processes driving the state variables (Whittle 1990).
} 
are smoothed over time, expected values of the tax rate gradually fall and/or expected levels of government spending increase over time as the inevitable windfall revenues materialize and the level of government debt and thus debt service fall over time. We show that the extent to which this happens is greater if the degree of prudence of the government, the variance and persistence of shocks hitting the national income and the tax base, and the tax rate are relatively high.

Another objective of this paper is to characterize the conditions under which it is desirable to have a prudent minister of finance within the government. Intuitively, a prudent minister of finance may be desirable for various reasons. If unexpected falls in public revenue appear, spending ministers spend lots of time and energy fighting over which one of them has to implement the spending cuts to balance the budget and the minister of finance is under great pressure to relax the budgetary rules. This is not conducive to good government. Too much time and energy is wasted on squabbling rather than on necessary reforms and cracking necessary tough political decisions. It is thus desirable to have a prudent budgetary policy, so that on average unexpected windfall revenues are more likely than shortfalls in expected revenues. Another justification of why it is desirable to have a minister of finance who is more prudent than the average voter is that ex ante the minister of finance realizes that ex post it will be hard to discipline the spending ministers in his cabinet. Profligate spending ministers and a weak minister of finance give rise to a common-pool problem. This results in an upward bias in public spending claims, a tilt of the government spending profile from the future towards the present and of the tax profile from the present to the future, and thus excessive accumulation of government debt (Persson and Tabellini 2000, Chap. 13; Velasco 2000). We formalize these insights by explicitly analyzing the strategic interaction between the minister of finance and the spending ministers in the cabinet.

We show that it is in the interest of society to appoint a relatively prudent minister of finance, which can offset the intertemporal spending, tax and debt biases resulting from the common-pool problem. If in addition the minister of finance has the unequivocal backing of the prime minister and has at least as many votes in the cabinet as the spending ministers combined, he also has sufficient power to overcome intratemporal biases resulting in an excessively large public sector. The prospect of being removed from office by a political rival who prefers different public goods (Alesina and Tabellini 1990) or a different size of the public sector (Persson and Svensson 1989) also gives the incumbent an incentive to spend more on its (pet) project and to run up a debt in order to tie the hands of its potential successor. Although we focus on conflict in the council of ministers and abstract from partisan preferences, such political distortions may strengthen the case for appointing a prudent minister of finance.

Section 2 extends the traditional theory of tax smoothing and determination of public debt to allow for endogenous public spending and for prudence, and derives our key insight about underestimating the tax base and building precautionary buffers. As a precaution, the tax rate is thus set higher while public spending is set lower. Government borrowing is still warranted for temporary government spending and to cover temporary losses of revenues in a recession. Section 3 demonstrates that with a fragmented government, ministers spend too much and too soon and postpone taxation. 
As a result of this dynamic common-pool problem, there is excessive accumulation of government debt. Section 4 shows that it is desirable in this context to appoint a strong and prudent minister of finance. Section 5 shows that too much prudence can be abused for short-term electoral gains. Section 6 concludes.

\section{Precautionary taxation and debt management with uncertainty about future income}

To keep matters simple, we assume only two time periods. If there is no inherited debt and the growth-corrected rate of interest and the discount rate are zero, we can write the present-value government budget constraint as

$$
d=g_{1}-\tau_{1}=\tau_{2}+\bar{\tau} \varepsilon-g_{2}, \quad \varepsilon \sim \operatorname{IN}\left(0, \sigma^{2}\right),
$$

where $g_{t}$ denotes the share of public spending in GDP at time $t, \tau_{t}$ the tax rate at time $t, d$ the debt-GDP ratio (or the deficit) at the end of the first period, $\bar{\tau}$ the tax rate around which the government budget constraint is linearized, and $\varepsilon$ the stochastic shock to GDP and the tax base in period 2. The stochastic shocks to income and the tax base are normally distributed with zero mean and variance $\sigma^{2}$. Any government debt incurred by the excess of spending over taxes in the first period must thus be paid off in the second period by an excess of taxes over spending. Henceforth, we follow Barro (1979) and assume that the government has a welfare loss function $\Gamma$ in terms of the squared tax rate to capture tax collection costs (or tax distortions). Since we are interested in the trade-off between tax cuts and public spending increases, we also include squared deviations of public spending from its bliss value in the welfare loss function (see Appendix for a rudimentary micro foundation). The government maximizes the following objective function:

$$
\Phi(\theta) \equiv-\frac{1}{\theta} \ln \left(E\left[\exp (\theta \Gamma) / d_{0}, y_{0}\right]\right) \quad \text { with } \Gamma \equiv \frac{1}{2} \sum_{t=1}^{2}\left(\tau_{t}^{2}+\chi\left(\hat{g}-g_{t}\right)^{2}\right)
$$

where $\chi>0$ denotes the priority attached to higher public spending and the bliss values of the tax rate and public spending are zero and $\hat{g}>0$, respectively. To allow for prudence, the government maximizes $\Phi(\theta)$ subject to the government budget constraint (1), where $\theta>0$ denotes the degree of prudence or caution of the government. The risk-neutral case corresponds to $\Phi(\theta) \rightarrow-E\left[\Gamma / d_{0}, y_{0}\right]$ as $\theta \rightarrow 0$. If $\theta \operatorname{var}(\Gamma)$ is small, $\Phi(\theta) \cong-E(\Gamma)+\frac{\theta}{2} \operatorname{var}(\Gamma)$, which in a local kind of way illustrates that $\theta$ also captures the degree of risk aversion. Two governments may share the same welfare criterion under certainty, but their aversion to risk may differ. The government maximizes (2) or equivalently the expected value of $U\left(\Gamma^{*}\right) \equiv-\exp \left(-\theta \Gamma^{*}\right)$ where $\Gamma^{*} \equiv-\Gamma$. The coefficient of absolute risk aversion, $\theta \equiv-U^{\prime \prime} / U^{\prime}>0$, also captures prudence, since $U^{\prime \prime \prime}=\theta^{3} \exp \left(-\theta \Gamma^{*}\right)>0$ (Kimball 1990). Prudence implies the willingness to avoid shocks with adverse consequences. In the optimal outcome government plays a game against Nature (Whittle 1990; 
van der Ploeg 1993):

$$
\operatorname{Min}_{\tau_{1}, \tau_{2}, g_{1}, g_{2}} \operatorname{Max}_{\varepsilon}\left(\sum_{t=1}^{2} \frac{1}{2}\left[\tau_{t}^{2}+\chi\left(\hat{g}-g_{t}\right)^{2}\right]\right)-\left(\frac{\varepsilon^{2}}{2 \theta \sigma^{2}}\right) \quad \text { subject to (1). }
$$

The government thus chooses the tax rate and public spending to minimize this minmax criterion and assumes the worst by postulating that the national income disturbance is drawn in a way that maximizes this criterion. This leads to the following expressions for the optimal first-period tax rate and public spending, the budgeted underestimation of national income $\left(\varepsilon^{B}\right)$ and public debt:

$$
\begin{gathered}
g_{1}=\left[\frac{2 \chi-\theta \sigma^{2} \bar{\tau}^{2} \chi}{2(\chi+1)-\theta \sigma^{2} \bar{\tau}^{2} \chi}\right] \hat{g} \leq\left(\frac{\chi}{\chi+1}\right) \hat{g}, \\
\tau_{1}=\left[\frac{2 \chi}{2(\chi+1)-\theta \sigma^{2} \bar{\tau}^{2} \chi}\right] \hat{g}>\left(\frac{\chi}{\chi+1}\right) \hat{g}>0 \\
\text { and } d=\left(\frac{\bar{\tau}}{2}\right) \varepsilon^{B}=-\left[\frac{\theta \sigma^{2} \bar{\tau}^{2} \chi}{2(\chi+1)-\theta \sigma^{2} \bar{\tau}^{2} \chi}\right] \hat{g} \leq E[\varepsilon]=0 \\
\text { provided } \theta<\frac{2(\chi+1)}{\sigma^{2} \bar{\tau}^{2} \chi} .
\end{gathered}
$$

Second-period public spending and the tax rate follow from the second-period budget constraint:

$$
g_{2}=\left(\frac{\chi \hat{g}-d+\bar{\tau} \varepsilon}{\chi+1}\right) \quad \text { and } \quad \tau_{2}=\left(\frac{\chi(\hat{g}+d-\bar{\tau} \varepsilon)}{\chi+1}\right)
$$

If the government is risk-neutral $(\theta=0)$, certainty equivalence holds and optimal first-period policies follow from setting $\varepsilon^{B}=0$. In that case, it is optimal to smooth the tax rates and the levels of public spending (i.e., $g_{1}=E\left[g_{2}\right]=\tau_{1}=E\left[\tau_{2}\right]=$ $\chi \hat{g} /(1+\chi))$ and to run a balanced budget $(d=0)$. If the national income turns out better than expected $(\varepsilon>0)$, there is room to lower the tax rate and increase public spending in the second period. With prudent policy making $(\theta>0)$, the government underestimates future income and tax base to be on the safe side $\left(\varepsilon^{B}<0\right)$. As a consequence, the first-period tax rate is set higher, first-period public spending is set lower and precautionary buffers are accumulated $(d<0)$. During the second period, the tax rate is lowered and public spending increased even without positive shocks to national income. Hence, precautionary buffers induce a downward tilt of tax rates and upward tilt of public spending. Governments who care more about tax distortions than spending targets (lower $\chi$ ) have lower tax rates and thus their correction for prudence is smaller also.

Proposition 1 It is prudent to have precautionary taxation and under-spending and build assets to safeguard against future adverse shocks to the tax base. The precautionary buffers and the windfall revenues allow taxes to fall and public spending to rise over time. 
These results can be extended to allow for infinite horizons, non-zero growthcorrected real interest rates and discount rates, non-zero inherited debt, and AR(1) processes for deviations of national income from trend (van der Ploeg 2007). ${ }^{3}$ The government then underestimates shocks to the tax base more strongly if prudence is substantial, variances and persistence of shocks are large, and the tax rate is high. The expected deficit is less than warranted by projected hikes in public spending or temporary recessions, especially if the degree of prudence, the variance of shocks to the tax base and the tax rate are relatively large. A temporary recession and fall in the tax base or a temporary increase in desired public spending (e.g., due to a war) are accommodated by a higher deficit, not by a higher tax rate. Permanent shocks to national income and the tax base or to the target level of public spending are accommodated by the tax rate, not by the deficit. The correction for prudence is much greater for permanent than temporary shocks, so the precautionary level of taxation is much higher. More persistent stochastic shocks to national income imply that it is prudent to have a larger budgeted underestimation of the tax base, which leads to more precautionary taxation, lower levels of public spending and bigger precautionary buffers (or reductions in public debt).

With a permanent fall in national income, say, the tax rate is higher and public spending is lower on impact than without prudence. On top of the interest on precautionary buffers, the government can on average expect windfall revenues that enable debt to be paid off. The resulting financial leeway permits a gradual rise in the level of public spending and fall in the tax rate. In the long run the government builds up sufficient interest-bearing assets to generate the interest revenue necessary to pay for the long-run increase in public spending and compensate for the fall in the tax base. The tax rate converges asymptotically to zero. In addition, public spending slowly climbs to its bliss value.

Although we have not specified micro foundations, our results will go through under some special assumptions. ${ }^{4}$ The micro-founded literature also finds that governments should accumulate claims on the private sector and use the interest revenue to get rid of labor market distortions. In representative-agent models with government commitment, this holds irrespective of whether there is capital accumulation or not and whether asset markets are complete (Chari et al. 1994) or incomplete (Aiyagari et

\footnotetext{
${ }^{3}$ One can also allow for unemployment benefits and public sector investment. The underestimation of the tax base is then larger if the unemployment benefit is higher. The higher the tax rate and the unemployment benefit, the more sensitive tax revenues and the benefit bill are to business cycle variations, the bigger the underestimation of the tax base. Prudence now also leads to under-spending on public investment projects. As a result, net worth of the public sector increases over time and the government can be expected to gradually lower the tax burden and gradually increase spending on consumption goods and capital.

${ }^{4}$ Our framework can be given micro foundations if utility is quasi-linear and utility of money is constant, labor supply and output are exogenous, disutility of work is quadratic in labor supply, production losses resulting from tax collection are proportional to the square of the tax rate, and households cannot accumulate assets. If also the government can borrow on the world markets against a given interest rate $r$, and the wage follows from the factor price frontier, expression (2) for social welfare corresponds to aggregate utility of households and the present-value budget constraint (1) is justified. It is more satisfying to recast Barro's model in a general equilibrium framework with incomplete markets and utility quasi-linear in consumption, so the government has no access to state-contingent debt and cannot manipulate intertemporal prices (e.g., Aiyagari et al. 2002).
} 
al. 2002). But with complete markets the planner must set an initial tax on debt to obtain an instantaneous and non-distortionary wealth transfer. With incomplete markets the same can be obtained in the long run by precautionary saving of the government. ${ }^{5}$

\section{Squabbling spending ministers}

Section 4 demonstrates that a case can be made for appointing a prudent finance minister, since such a finance minister is better able to fend off the unfettered claims of the spending ministers. Before this is done, we discuss the dynamic common-pool problem for budgetary policies with a fragmented government without prudence. Each spending minister wants a large share of revenues and is not particularly interested in balancing the budget. Ex ante the minister of finance realizes that ex post it is tougher to discipline the spending ministers in his cabinet. If the minister of finance is not in firm control, the unfettered claims of the spending ministers give rise to a commonpool problem. This implies an upward bias in public spending and excessive accumulation of government debt as discussed in Persson and Tabellini (2000, Chaps. 13.1 and 13.2). ${ }^{6}$ It also induces a departure from tax smoothing, since spending ministers try to defer taxation and spending cuts. Such biases occur as each spending minister tries to get its hands on scarce public revenue before the other spending ministers get a chance to do so. To make the point, we allow for $N$ spending ministers. The present-value government budget constraint can now be written as:

$$
d=\sum_{i=1}^{N} g_{1 i}-\tau_{1}=\tau_{2}+\bar{\tau} \varepsilon-\sum_{i=1}^{N} g_{2 i}, \quad \varepsilon \sim \mathrm{N}\left(0, \sigma^{2}\right),
$$

where $g_{t i}$ indicates spending by minister $i$ at time $t$. We focus on symmetric outcomes and thus set the same priorities and bliss values for all public spending categories. Minister $i$ is concerned with minimizing the expected welfare loss:

$$
L_{i} \equiv E\left[\frac{1}{2} \sum_{t=1}^{2}\left(\tau_{t}^{2}+\chi\left(\hat{g}-g_{t i}\right)^{2}\right)\right] \text {. }
$$

\footnotetext{
${ }^{5}$ With heterogeneous agents households accumulate public debt as buffer against individual idiosyncratic shocks while the planner prefers to accumulate private debt as buffer against aggregate risk (Aiyagari 1995; Aiyagari and McGrattan 1998). Long-run government debt will then occur only if idiosyncratic risk is more important than aggregate risk and there are no other assets that allow self-insurance (Shin 2006).

${ }^{6}$ The spending bias resulting from fiscal illusion (i.e., the overestimation of the benefit of a particular activity) may be contained by appropriate budgetary processes, which depend on what kind of uncertainty dominates the budget process (Von Hagen and Harden 1995). Another way to constrain profligate spending ministers is to delegate authority to monitor and punish to the minister of finance. This may work better in countries with non-proportional representation and one-party states (Hallerberg and von Hagen 1997). Appointment of a spending-averse minister of finance is better than binding budget targets imposed by the prime minister, because it induces spending ministers to propose less ambitious budgets and appoint less spending-prone bureaucrats (Swank 2002).
} 
The minister of finance minimizes the expected value of the sum of the welfare loss functions of each of the spending ministers and also postulates that future disturbances are drawn to hurt social welfare. We first consider the cooperative outcome, where the minister of finance and the spending ministers jointly minimize the expected value of the social welfare loss $L_{1}+\cdots+L_{N}$ subject to $\left(1^{\prime}\right)$ in the absence of prudence. We then contrast this with the non-cooperative outcome in the absence of prudence where spending ministers lead in their spending claims and the minister of finance follows in setting the tax rate and public debt. We show that the noncooperative outcome leads to the following distortions: a tilt towards future rather than present taxation, a tilt towards present rather than future public consumption, excessive accumulation of government debt, and an upward bias in total public spending and the average tax rate.

\subsection{Cooperative outcome}

It is easy to show that the cooperative outcome in the absence of prudence is characterized by

$$
\begin{aligned}
& g_{1 i}^{C}=E\left(g_{2 i}^{C}\right)=\left(\frac{\chi}{\chi+N^{2}}\right) \hat{g}<\hat{g}, \quad g_{2 i}^{C}=g_{1 i}^{C}+\left(\frac{N}{\chi+N^{2}}\right) \bar{\tau} \varepsilon_{2}, \quad i=1, \ldots, N, \\
& d_{1}^{C}=0, \\
& \tau_{1}^{C}=E\left(\tau_{2}^{C}\right)=\left(\frac{\chi}{\chi+N^{2}}\right) N \hat{g}, \quad \text { and } \quad \tau_{2}^{C}=\tau_{1}^{C}-\left(\frac{\chi}{\chi+N^{2}}\right) \bar{\tau} \varepsilon_{2},
\end{aligned}
$$

where superscript $C$ indicates the cooperative outcome. It is optimal ex ante for the social planner to smooth the levels of public spending and the tax rate over time. Since there are no changes in the targets for government spending or the tax base over time, there is no need for government debt. A bigger priority to public goods $\chi$ leads to higher spending and tax rates.

\subsection{Nash outcome with pre-commitment}

One way to calculate the non-cooperative outcome is to assume pre-commitment of each spending minister to future spending levels. The resulting open-loop Nash equilibrium is

$$
\begin{gathered}
g_{1 i}^{C}=E\left(g_{2 i}^{C}\right)<g_{1 i}^{O}=E\left(g_{2 i}^{O}\right)=\left(\frac{\chi}{\chi+N}\right) \hat{g}<\hat{g}, \quad d_{1}^{O}=0, \\
\tau_{1}^{C}=E\left(\tau_{2}^{C}\right)<\tau_{1}^{O}=E\left(\tau_{2}^{O}\right)=\left(\frac{\chi ?}{\chi+N}\right) N \hat{g},
\end{gathered}
$$

where the superscript $O$ indicates the open-loop Nash outcome. In the noncooperative outcome with pre-commitment, we see that spending and tax rates are higher than in the cooperative outcome. Since spending ministers are only concerned with their own budget, they do not take full account of the tax distortions caused by the total budget. Tax rates and public spending levels are smoothed, so there is 
no need for government debt. Hence, there are no intertemporal distortions, only intratemporal distortions in the Nash outcome with pre-commitment. If the minister of finance and the prime minister together get just as many votes as the spending ministers combined, the Nash outcome with pre-commitment becomes the cooperative outcome and the intratemporal distortions leading to an excessively large public sector are eliminated.

\subsection{Subgame-perfect Nash outcome}

It is more realistic to assume that there is no pre-commitment in which case the subgame-perfect Nash outcome is appropriate. Working backwards each spending minister takes past government debt and spending plans of his colleagues as given. Minister $i$ thus solves, in the second period,

$$
\begin{aligned}
L_{2 i} & \equiv \operatorname{Min}_{g_{2 i}} \frac{1}{2}\left[\tau_{2}^{2}+\chi\left(\hat{g}-g_{2 i}\right)^{2}\right] \\
& =\frac{1}{2}\left[\left(d_{1}-\bar{\tau} \varepsilon_{2}+\sum_{j=1}^{N} g_{2 j}\right)^{2}+\chi\left(\hat{g}-g_{2 i}\right)^{2}\right], \quad i=1, \ldots, N,
\end{aligned}
$$

where we have substituted the second-period budget constraint from $\left(1^{\prime}\right)$. The optimal reaction function for minister $i$ is thus given by

$$
g_{2 i}=\frac{\chi \hat{g}-d_{1}+\bar{\tau} \varepsilon_{2}-\sum_{j \neq i} g_{2 j}}{1+\chi}, \quad i=1, \ldots, N,
$$

so that he spends more if there is a small outstanding debt and a positive income shocks. If his colleagues spend more, the cost of funds goes up and he spends less. The resulting symmetric Nash equilibrium for the second-period level of spending and the tax rate is given by

$$
g_{2 i}^{N}=\frac{\chi \hat{g}-d_{1}+\bar{\tau} \varepsilon_{2}}{N+\chi}, \quad i=1, \ldots, N \quad \text { and } \quad \tau_{2}^{N}=\left(\frac{\chi}{N+\chi}\right)\left(N \hat{g}+d_{1}-\bar{\tau} \varepsilon_{2}\right),
$$

where the superscript $N$ indicates the subgame-perfect Nash outcome. Turning to the first period and substituting the first part of $\left(1^{\prime}\right)$ and (11) into (6), we see that minister $i$ chooses first-period spending to minimize its welfare loss:

$$
\begin{aligned}
L_{i}^{N}= & \operatorname{Min}_{g_{1 i}} E\left(\frac{1}{2} \tau_{1}^{2}+\frac{1}{2} \chi\left(\hat{g}-g_{1 i}\right)^{2}\right. \\
& \left.+\frac{1}{2}\left(\frac{\chi(1+\chi)}{(N+\chi)^{2}}\right)\left[N \hat{g}+\left(\sum_{j=1}^{N} g_{1 j}\right)-\tau_{1}-\bar{\tau} \varepsilon_{2}\right]^{2}\right),
\end{aligned}
$$

and the finance minister chooses the tax rate $\tau_{1}$ to minimize $L_{1}+\cdots+L_{N}$. The resulting first-order conditions are 


$$
\chi\left(\hat{g}-g_{1 i}\right)=\tau_{1}=\left(\frac{\chi(1+\chi)}{(N+\chi)^{2}}\right)\left(N \hat{g}+N g_{1 i}-\tau_{1}\right),
$$

which states that the marginal cost of taxation must equal the marginal benefit of public goods in the first period and also equal the marginal cost of public debt (i.e., the marginal cost of lower spending and higher taxes in the future). The resulting symmetric subgame-perfect Nash equilibrium outcomes for the first period are

$$
\begin{aligned}
& g_{1 i}^{N}=\left[\frac{(N+\chi)^{2}+(\chi-N)(1+\chi)}{(N+\chi)(N+2 \chi+1)}\right] \hat{g}, \quad i=1, \ldots, N, \\
& \tau_{1}^{N}=\left[\frac{2 \chi(1+\chi)}{(N+\chi)(N+2 \chi+1)}\right] N \hat{g} \\
& \text { and } d_{1}^{N}=\left[\frac{(N+\chi)^{2}-(\chi+N)(1+\chi)}{(N+\chi)(N+2 \chi+1)}\right] N \hat{g}>0 .
\end{aligned}
$$

Due to the linear-quadratic-Gaussian nature of the optimization problem and the absence of prudence, certainty equivalence applies, so optimal first-period spending and debt can be obtained by setting the future income shock to its expected value of zero. Upon substitution of (14) into (11), we obtain the subgame-perfect Nash outcomes for the second period:

$$
\begin{aligned}
& g_{2 i}^{N}=\left[\frac{\chi(N+2 \chi+1)-N(N-1)}{(N+\chi)(N+2 \chi+1)}\right] \hat{g}+\left(\frac{\bar{\tau} \varepsilon_{2}}{N+\chi}\right), \quad i=1, \ldots, N, \\
& \text { and } \tau_{2}^{N}=\left[\frac{2 \chi}{(N+\chi)(N+2 \chi+1)}\right] N \hat{g}-\left(\frac{\chi}{N+\chi}\right) \bar{\tau} \varepsilon_{2} .
\end{aligned}
$$

\subsection{Comparing outcomes}

As long as $N>1$, we can easily establish the following results:

$$
\begin{aligned}
& g_{1 i}^{N}>E\left(g_{2 i}^{N}\right), \quad g_{1 i}^{N}>g_{1 i}^{O}>g_{1 i}^{C}=E\left(g_{2 i}^{C}\right), \quad E\left(g_{2 i}^{N}\right)<E\left(g_{2 i}^{O}\right), \\
& g_{1 i}^{N}+E\left(g_{2 i}^{N}\right)=g_{1 i}^{O}+E\left(g_{2 i}^{O}\right)>g_{1 i}^{C}+E\left(g_{2 i}^{C}\right), \\
& L_{i}^{N}>L_{i}^{C}>L_{i}^{C}, \quad i=1, \ldots, N, \\
& E\left(\tau_{2}^{N}\right)>\tau_{1}^{N}>\tau_{1}^{C}=E\left(\tau_{2}^{C}\right) \quad \text { and } \quad d_{1}^{N}>0 .
\end{aligned}
$$

From (15) and (16) we see that the subgame-perfect Nash outcome suffers from two types of distortions. First, the sum of spending levels and of the tax rate over the two periods is the same as in the Nash equilibrium with pre-commitment and thus higher than in the cooperative outcome. This is the familiar intratemporal distortion towards an excessive public sector. Second, government consumption is tilted towards the first period, taxation is tilted towards the second period, and, as a consequence, there is excessive government debt. These are the intertemporal distortions. In fact, spending in the first period is greater in the subgame-perfect Nash than in the cooperative 
outcome. $^{7}$ Since each spending minister (or group of a coalition) decides part of the budget and nobody controls the aggregate budgetary outcome, ministers spend too much and too soon and postpone taxation so that borrowing is too high. These two types of common-pool distortions arise from the lack of a proper definition of property rights to tax revenues.

The common-pool distortions worsen when the number of spending ministers increases. More claims on the common budget worsen the biases to spend too much and too soon and postpone taxation. Also, comparing (15) with (7), a positive shock to national income induces a smaller increase in public spending and the tax rate in the non-cooperative outcome. Finally, the expected welfare loss is obviously greater in the subgame-perfect Nash than in the Nash outcome with pre-commitment and $a$ fortiori so than in the cooperative outcome.

Proposition 2 A fragmented government leads to a dynamic common-pool problem. The government spends too much and too soon while it postpones taxation. Consequently, there is too much government debt. Since eventually debt has to be paid off, the tax rate rises and the spending level falls over time. These intertemporal and intratemporal distortions become more severe when there are many spending ministers.

\section{Case for a strong and prudent minister of finance}

A key question is how the common-political distortions arising from fragmented decision making can be offset. We conjecture that this can be done if the minister of finance is strong and prudent enough. A strong minister of finance may help to overcome the intratemporal distortions of spending and taxing too much. A prudent minister of finance deliberately underestimates the tax base and thus ensures that government spending occurs later than sooner while taxation occurs earlier rather than later. As a result, a prudent finance minister can offset the debt bias and the intertemporal distortions of the common-pool problem. We are thus searching for a relatively strong priority of avoiding tax distortions, i.e., a weight $\chi^{*}$ lower than the weight $\chi$ given by the spending ministers to reaching the spending target, and a level of prudence $\theta^{*}$ that will offset the intertemporal biases of fragmented policy making.

Of course, if the electorate itself is prudent, it makes sense for a benevolent government to be prudent as well. However, even if the electorate and the spending ministers are not prudent, it may be attractive to appoint a minister of finance with more prudent preferences than the electorate and his spending colleagues. More precisely, a minister of finance can strengthen his position in the cabinet by implementing a prudent budgetary policy to offset the biases resulting from the common-pool problem. It is thus in the interest of society to appoint a prudent minister of finance who deliberately underestimates the future tax base and enforces precautionary taxation and under-spending. In as far as a strong and prudent minister of finance is able to offset the distortions of the dynamic common-pool problem and control the squabbling spending ministers, social welfare will be increased to its socially optimal level.

${ }^{7}$ Also, if $\chi(2 \chi+N)>N^{2}$, we establish that $E\left(g_{2 i}^{N}\right)>g_{1 i}^{C}=g_{2 i}^{C}$. 
Consider therefore a strong and prudent finance minister with $\chi^{*}<\chi$ and $\theta>0$ and examine how this affects the subgame-perfect Nash outcome of Sect. 3 and see whether this can improve social welfare. The cabinet will then deliberately depress forecasts of future national income and the tax base. The finance minister is prudent and solves the min-max problem:

$$
\begin{gathered}
\underset{\tau_{1}}{\operatorname{Min}} \operatorname{Max}_{\varepsilon_{2}} \frac{1}{2}\left[\sum _ { i = 1 } ^ { N } \left(\tau_{1}^{2}+\chi^{*}\left(\hat{g}-g_{1 i}\right)^{2}+\left(\frac{\chi^{*}\left(1+\chi^{*}\right)}{\left(N+\chi^{*}\right)^{2}}\right)\right.\right. \\
\left.\left.\times\left[N \hat{g}+\left(\sum_{j=1}^{N} g_{1 j}\right)-\tau_{1}-\bar{\tau} \varepsilon_{2}\right]^{2}\right)-\left(\frac{\varepsilon_{2}^{2}}{\theta \sigma^{2}}\right)\right] .
\end{gathered}
$$

This gives rise to the following first-order conditions:

$$
-\left(\frac{\varepsilon_{2}^{B}}{N \theta \sigma^{2} \bar{\tau}}\right)=\chi^{*}\left(\hat{g}-g_{1 i}\right)=\tau_{1}=\left(\frac{\chi^{*}\left(1+\chi^{*}\right)}{\left(N+\chi^{*}\right)^{2}}\right)\left(N \hat{g}+N g_{1 i}-\tau_{1}-\bar{\tau} \varepsilon_{2}^{B}\right) .
$$

Using $\left(13^{\prime}\right)$ and (15) to substitute expressions for all variables in terms of $\tau_{1}$ into the present-value budget constraint $\left(1^{\prime}\right)$ yields the following expressions for the firstperiod tax rate and level of spending, public debt and the future budgeted income shock:

$$
\begin{aligned}
& \varepsilon_{2}^{B}=-\left(\frac{2 \theta \sigma^{2} \tau N \chi^{*}\left(1+\chi^{*}\right)}{\left(N+\chi^{*}\right)\left(N+2 \chi^{*}+1\right)-\theta \sigma^{2} \bar{\tau}^{2} N \chi^{*}\left(1+\chi^{*}\right)}\right) N \hat{g}<E\left(\varepsilon_{2}\right)=0, \quad \text { (17) } \\
& g_{1 i}^{F}=\left[\frac{\left(N+\chi^{*}\right)^{2}+\left(\chi^{*}-N\right)\left(1+\chi^{*}\right)-\theta \sigma^{2} \bar{\tau}^{2} N \chi^{*}\left(1+\chi^{*}\right)}{\left(N+\chi^{*}\right)\left(N+2 \chi^{*}+1\right)-\theta \sigma^{2} \bar{\tau}^{2} N \chi^{*}\left(1+\chi^{*}\right)}\right] \hat{g}, \quad i=1, \ldots, N, \\
& \tau_{1}^{F}=\left[\frac{2 \chi^{*}\left(1+\chi^{*}\right)}{\left(N+\chi^{*}\right)\left(N+2 \chi^{*}+1\right)-\theta \sigma^{2} \bar{\tau}^{2} N \chi^{*}\left(1+\chi^{*}\right)}\right] N \hat{g}>0 \\
& \text { and } d_{1}^{F}=\left[\frac{\left(N+\chi^{*}\right)^{2}-\left(\chi^{*}+N\right)\left(1+\chi^{*}\right)-\theta \sigma^{2} \bar{\tau}^{2} N \chi^{*}\left(1+\chi^{*}\right)}{\left(N+\chi^{*}\right)\left(N+2 \chi^{*}+1\right)-\theta \sigma^{2} \bar{\tau}^{2} N \chi^{*}\left(1+\chi^{*}\right)}\right] N \hat{g}>0 .
\end{aligned}
$$

Here superscript $F$ indicates the outcome with a prudent minister of finance. Expression (17) indicates that the minister of finance deliberately underestimates future income to be on the safe side. Second-period public spending and the tax rate follow readily from the second-period government budget constraint:

$$
g_{2 i}^{F}=\left(\frac{\chi^{*} \hat{g}-d_{1}^{F}+\varepsilon_{2}}{\chi^{*}+N}\right) \quad \text { and } \quad \tau_{2}^{F}=\left(\frac{N \hat{g}+d_{1}^{F}-\bar{\tau} \varepsilon_{2}}{\chi^{*}+N}\right) .
$$


Proposition 3 If the minister of finance has as much power as all the spending ministers combined and has enough, but not too much prudence,

$$
\begin{aligned}
& \chi^{*}=\chi / N<\chi \text { and } \theta=\frac{\left(N+\chi^{*}\right)(N-1)}{N \chi^{*}\left(1+\chi^{*}\right) \bar{\tau}^{2} \sigma^{2}}=\frac{\left(N^{2}+\chi\right)(N-1)}{\chi(N+\chi) \bar{\tau}^{2} \sigma^{2}} \equiv \theta^{*}>0 \\
& \quad \text { if } N>1,
\end{aligned}
$$

the intratemporal and intertemporal distortions of the common-pool problem are exactly offset and the cooperative outcome is attained. If the degree of prudence is less than this critical value $\left(\theta<\theta^{*}\right)$, the common-pool distortions dominate the effects of prudence. Hence, government debt will be positive and spending will be too soon and taxation too late. If the degree of prudence is bigger $\left(\theta>\theta^{*}\right)$, the government builds up assets and thus spending is too late and taxation too soon. If the minister of finance is less strong $\left(\chi^{*}<\chi / N\right)$, the public sector will be too big.

Proof Equation (18) implies from (14') that $d_{1}^{F}=0$ and thus that $\tau_{1}^{F}=\tau_{1}^{C}$ and $g_{1 i}^{F}=$ $g_{1 i}^{C}$. The results for when $\theta$ is less or greater than $\theta^{*}$ follow immediately.

The biases of spending too much and too soon and delaying taxation are thus offset by a sufficiently strong and prudent minister of finance. If the minister of finance is not strong enough, he cannot control its profligate and impatient spending colleagues. If the minister of finance effectively has as much power as all his spending colleagues together, it eliminates the intratemporal distortions. Precautionary taxation and underspending allow for a gradual reduction in government debt. They also lead on average to expected windfall revenues, so that over time the level of public spending can rise and the tax rate can fall. Prudence is thus able to offset the intertemporal distortions arising from the dynamic common-pool problem.

The calculations in Table 1 illustrate these two ways of correcting the biases. The Nash equilibrium with pre-commitment only suffers from intratemporal distortions:

Table 1 Strong and prudent finance minister mitigates common-pool problem

\begin{tabular}{llllllll}
\hline & $N g_{1 i}$ & $N g_{2 i}$ & $d_{1}$ & $\tau_{1}$ & $\tau_{2}$ & $\varepsilon_{2}^{B}$ & $L_{i}$ \\
\hline Cooperative & 0.3333 & 0.3333 & 0 & 0.3333 & 0.3333 & 0 & 0.2 \\
Nash: commitment & 0.4286 & 0.4286 & 0 & 0.4286 & 0.4286 & 0 & 0.2204 \\
Nash: perfect & 0.4418 & 0.4154 & 0.0462 & 0.3956 & 0.4615 & 0 & 0.2217 \\
Prudent $\theta \sigma^{2} \bar{\tau}=0.1$ & 0.4386 & 0.4186 & 0.0350 & 0.4036 & 0.4536 & -0.0807 & 0.2212 \\
Prudent $\theta \sigma^{2} \bar{\tau}=0.2$ & 0.4352 & 0.4219 & 0.0233 & 0.4119 & 0.4452 & -0.1648 & 0.2207 \\
Prudent $\theta \sigma^{2} \bar{\tau}=0.35$ & 0.4300 & 0.4272 & 0.0050 & 0.4250 & 0.4321 & -0.2975 & 0.2204 \\
Prudent $\theta \sigma^{2} \bar{\tau}=0.4$ & 0.4282 & 0.4290 & -0.0014 & 0.4296 & 0.4275 & -0.3437 & 0.2204 \\
Strong and prudent & & & & & & & \\
$\chi^{*}=2.5, \theta \sigma^{2} \bar{\tau}=0.4$ & 0.3522 & 0.3145 & 0.0425 & 0.3097 & 0.3569 & -0.2478 & 0.2010 \\
$\chi^{*}=2.5, \theta \sigma^{2} \bar{\tau}=0.8$ & 0.3358 & 0.3308 & 0.0057 & 0.3302 & 0.3365 & -0.5283 & 0.2000 \\
\hline
\end{tabular}

Parameters: $\bar{\tau}=\hat{g}=0.3, \chi=5$ and $N=2$ 
government spending levels and tax rates are higher than in the cooperative outcome $(0.4286>0.3333)$, but there is no excessive debt accumulation $\left(d_{1}=0\right)$. To get rid of this bias, it suffices to give the minister of finance at least as many votes in the cabinet as the spending ministers combined (i.e., reduce $\chi=5$ to $\chi^{*}=\chi / N=2.5$ ). The subgame-perfect Nash outcome gives rise to the intertemporal distortions of spending too soon, taxing too late and excessive debt accumulation, but average spending levels and tax rates correspond exactly to the ones in the equilibrium with pre-commitment (i.e., $\frac{1}{2}(0.4418+0.4154)=\frac{1}{2}(0.3956+0.4615=0.4286)$. Prudent budgetary policy offsets the bias of spending too much and too soon and the resulting debt bias. By deliberately budgeting the future national income and tax revenues too low, the minister of finance forces his spending colleagues to spend later, to not postpone taxation and to accumulate less debt. As the degree of prudence $\theta \sigma^{2} \tau$ increases towards 0.8571 as predicted by (18), it is optimal to spend less today and more tomorrow, to borrow less and bring forward taxation. If $\theta \sigma^{2} \tau$ approaches 0.3889 (i.e., the expression for $\theta$ in (18) evaluated at $\chi^{*}=\chi=5$ ), the debt bias completely disappears and the subgame-perfect Nash outcome with prudence has become the Nash outcome with pre-commitment. The final rows show that with a strong and even more prudent minister of finance (i.e., with $\chi^{*}=2.5$ and $\theta \sigma^{2} \bar{\tau}=0.8571$ ), all intratemporal and intertemporal welfare losses arising from the common-pool problem are mitigated.

The case for a strong and prudent minister of finance is strengthened by the following qualitative argument. Governments need to spend as much of their time and energy as possible on important and necessary economic and political reforms and cannot afford to waste political momentum on squabbling. However, whenever there are unexpected falls in public revenues, ministers taking care of the spending departments fight over who must implement the spending cuts to balance the budget and the minister of finance is pressurized to relax the budgetary rules. In contrast, if there are windfall revenues, the cabinet members find it easier to agree on what to do with them. The government may thus find it attractive to have a prudent budgetary policy, so that on average unexpected windfall revenues occur more frequently than shortfalls in expected revenues and more time and energy is left for important political matters.

Our normative results and especially the highlighted intra-governmental benefits of appointing a prudent finance minister hinge on the particular specification of the welfare function we have adopted. In particular, the potential benefits of a prudent finance minister depend on the squared terms for the tax rates and public spending in our ad hoc welfare criterion capturing true welfare and offering reliable insights.

\section{Warning: prudence may solicit electoral budget cycles}

Many governments adopt a 'first-sour-then-sweet' policy whereby unpopular policies such as raising tax rates and trimming public spending are implemented immediately upon election into office while popular policies of cutting tax rates and boosting public spending occur just before the next election. There may be short-run political benefits from loosening budgetary discipline just before an election, but only if citizens are myopic. ${ }^{8}$ Such opportunistic political manipulation is made possible by

\footnotetext{
${ }^{8}$ The pioneering work of Nordhaus (1975) on the political business cycle is based on myopic citizens. Opportunistic, pre-election manipulation of the expectations-augmented Phillips curve creates jobs on
} 
the assets accumulated from precautionary taxation and under-spending. By reducing government debt and accumulating assets, the minister of finance builds up a buffer that can be used to cut taxes and boost public spending towards election eve. As long as this is not overdone, electoral cycle motivations may help to offset the intertemporal common-pool distortions of spending too soon and taxing too late. However, there is the danger that excessively large buffers are accumulated by the minister of finance in order to dish out excessively big tax cuts and spending hikes on election eve for short-run political gains. ${ }^{9}$ Short-run political manipulation of election results may thus lead to an excessively prudent budgetary policy. To see this, we change the weight on second-period welfare losses in (6) from 1 to $1+\pi$ with $\pi>0$ and recalculate the outcomes of Table 1 . The first-order conditions are modified in the following way:

$$
\begin{aligned}
-\left(\frac{\varepsilon_{2}^{B}}{N \theta \sigma^{2} \bar{\tau}}\right)=\chi^{*}\left(\hat{g}-g_{1 i}\right)= & \tau_{1} \\
= & (1+\pi)\left(\frac{\chi^{*}\left(1+\chi^{*}\right)}{\left(N+\chi^{*}\right)^{2}}\right) \\
& \times\left(N \hat{g}+N g_{1 i}-\tau_{1}-\bar{\tau} \varepsilon_{2}^{B}\right) .
\end{aligned}
$$

Hence, following the same procedure as before, we find

$$
\begin{aligned}
\tau_{1}^{E}= & {\left[\frac{2(1+\pi) \chi^{*}\left(1+\chi^{*}\right)}{\left(N+\chi^{*}\right)^{2}+(1+\pi)\left[\left(N+\chi^{*}\right)\left(1+\chi^{*}\right)-\theta \sigma^{2} \bar{\tau}^{2} N \chi^{*}\left(1+\chi^{*}\right)\right]}\right] } \\
& \times N \hat{g}>0
\end{aligned}
$$

whence $N g_{1 i}^{E}=N \hat{g}-\tau_{1}^{F}, \quad i=1, \ldots, N$,

$d_{1}^{E}=N g_{1 i}^{E}-\tau_{1}^{E}, \quad \varepsilon_{2}^{B}=-\theta \sigma^{2} \bar{\tau}^{2} N \tau_{1}^{E}$,

$N g_{1 i}^{E}=\left(\frac{N}{N+\chi^{*}}\right)\left(\chi^{*} \hat{g}-d_{1}^{E}+\bar{\tau} \varepsilon_{2}^{B}\right)$

and $\tau_{2}^{E}=\left(\frac{\chi^{*}}{N+\chi^{*}}\right)\left(N \hat{g}+d_{1}^{E}-\bar{\tau} \varepsilon_{2}^{B}\right)$,

election eve while the inflationary effects appear after the election. Apart from not fitting the empirical facts very well (Drazen 2000), it is unlikely that people are foolish and irrational enough to be manipulated in such a way. Also, electoral cycles seem to be driven more by fiscal policy than monetary policy. Such opportunistic, pre-electoral manipulation can be rationalized when there is imperfect information about an incumbent's competence (Rogoff 1990). In such a context expansionary policy before an election indicates high competence. Partisan differences about the size of the public sector or the nature of public goods can also induce a pre-election debt bias (e.g., Persson and Tabellini 2000, Chap. 13.3).

9Indeed, the 'prudent' finance minister Gerrit Zalm has been accused of being tough in post-election years but exuberant and irresponsible in each pre-election year. Critics argue that under his reign the structural deficit and volatility of output and consumption have increased, but that he was 'saved' by the extra gas revenues resulting from temporary high oil prices (Jacobs 2007; Beetsma and van Wijnbergen 2007). Minister Zalm may thus have abused his 'prudent' budgetary policy for short-run electoral gains. The same critics complain that minister Zalm has in election years immediately converted temporary windfall revenues into permanent tax cuts $(1998,2005)$ or public spending hikes (2001). 
Table 2 Opportunistic manipulation of election outcomes

\begin{tabular}{lllllll}
\hline & $N g_{1 i}$ & $N g_{2 i}$ & $d_{1}$ & $\tau_{1}$ & $\tau_{2}$ & $L_{i}$ \\
\hline$\pi=0.15, \theta \sigma^{2} \bar{\tau}=0$ & 0.3482 & 0.3185 & 0.0334 & 0.3148 & 0.3519 & 0.2006 \\
$\pi=0.29, \theta \sigma^{2} \bar{\tau}=0$ & 0.3333 & 0.3333 & 0 & 0.3333 & 0.3333 & 0.2 \\
$\pi=0.45, \theta \sigma^{2} \bar{\tau}=0$ & 0.3173 & 0.3493 & -0.0360 & 0.3534 & 0.3133 & 0.2007 \\
$\pi=0.15, \theta \sigma^{2} \bar{\tau}=0.4$ & 0.3313 & 0.3354 & -0.0046 & 0.3359 & 0.3308 & 0.2133 \\
$\pi=0.15, \theta \sigma^{2} \bar{\tau}=0.857$ & 0.3089 & 0.3577 & -0.0549 & 0.3638 & 0.3028 & 0.2151 \\
$\pi=0, \theta \sigma^{2} \bar{\tau}=0.503$ & 0.3482 & 0.3185 & 0.0034 & 0.3148 & 0.3519 & 0.2006 \\
\hline
\end{tabular}

Parameters: $\bar{\tau}=\hat{g}=0.3, \chi^{*}=2.5$ and $N=2$

where the superscript $E$ denotes this electoral outcome. It is easy to show that (19) implies an electoral business cycle with higher taxes and lower spending upon moving into office and lower taxes and higher spending just before the next election. The government thus has an incentive to build up assets towards election eve in order to dish out favors to the voters.

The first three rows of Table 2 show what happens in the presence of a strong and opportunistic (but not a prudent) minister of finance. For small values of $\pi$ it is possible to have a welfare improvement vis-à-vis the subgame-perfect Nash outcome with $\chi^{*}=2.5$, but for large values of $\pi$ opportunistic political manipulation is excessive and leads to a deterioration of welfare. In other words, if the electorate 'forgets' past outcomes quickly, electoral budget cycles are more likely to reduce welfare. Modest short-run manipulation of election outcomes ensures, like prudence, more effective political decision making and makes it possible to control squabbling spending ministers, but not if public debt or assets induce excessive electoral budget cycles to the detriment of social welfare. If the electorate's effective discount rate of the past equals $1 / 1.2857=0.7777$ (or $\pi=0.2857$ ), the opportunistic electoral outcome exactly reproduces the first-best cooperative outcome. In that case, the intertemporal common-pool distortions are exactly offset by just the right amount of opportunistic manipulation of election results. In general, this happens if public debt is zero and the rate of memory loss of the electorate equals

$$
1+\pi=\frac{\left(N+\chi^{*}\right)^{2}}{\left[N+\chi^{*}\left(1+\theta \sigma^{2} \bar{\tau}^{2} N\right)\right]\left(1+\chi^{*}\right)}>\frac{N+\chi^{*}}{1+\chi^{*}} \quad \text { if } \theta \sigma^{2} \bar{\tau}>0 .
$$

Expression (20) indicates that a strong and prudent minister of finance needs to be less opportunistic to ensure that the first-best outcome is attained. The fourth and fifth rows of Table 2 illustrate this for a rate of memory loss $\pi=0.15$. Note that introducing prudence even a little to below a level that was necessary to generate the first-best outcome in the absence of memory loss, i.e., $\theta \sigma^{2} \bar{\tau}<0.857$ (see Table 1), there is already accumulation of public assets. Less prudence is thus needed to ensure the first-best outcome if the electorate has memory loss. Clearly, an opportunistic minister of finance builds up assets to present nice results on election eve. A minister of finance may not want to be seen to be involved in opportunistic manipulation of election results even though the electorate has memory loss of $\pi=0.15$. The minister 
of finance can then obtain a similar flattering election outcome by adopting a prudent budgetary policy. The final row of Table 2 illustrates that the minister of finance can then approach opportunistic outcome of the first row by setting the level of prudence equal to 0.503 .

Proposition 4 If the electorate weighs outcomes on election eve more heavily than those in the early part of the incumbency, politicians are encouraged to cut taxes and raise spending financed by running up government debt just before an election. As a result, a less prudent budgetary policy is required to offset the intertemporal distortions arising from squabbling spending ministers and attain the first-best outcome. The danger is that too much prudence is abused by opportunistic ministers of finance.

\section{Concluding remarks}

Principles of sound prudent budgetary policy require that the minister of finance deliberately underestimate the future level of the national income and the tax base, especially if the variance and persistence of shocks hitting national income and the tax base are large, and the level of the tax rate (and the unemployment benefit) is large. The principle of precautionary taxation thus requires that the tax rate be set higher than it would have been done otherwise. As precaution, the level of public spending is also set lower. Due to build-up of precautionary buffers and also the likely realization of windfall revenues, government debt falls over time. The associated reduction in debt service permits, depending on political preferences, either a gradual reduction in the tax rate, an increase in the public spending or a combination of both.

An important advantage of prudent budgetary policy is that it generates peace and quiet in the council of ministers. Without prudent forecasts of national income and the tax base, the likelihood of unexpected falls in tax receipts and consequent budgetary fights is much bigger. The ministers then waste a lot of time and energy on squabbling to try to offload the costs of further cuts on their colleagues. That time and energy would have been much better spent on important policy issues and reforms. With spending ministers squabbling over a common pool of public revenues, it is attractive to give the minister of finance at least as many voting rights in the cabinet as all the spending ministers combined. This eliminates the intratemporal common-pool distortions of an excessively large public sector. The minister of finance should also adopt a prudent budgetary policy to avoid spending too soon and taxing too late. This gets rid of the intertemporal common-pool distortions. A strong and prudent minister of finance can thus control the claims of his spending colleagues and avoid excessive debt accumulation.

It is straightforward to extend the present framework to allow for uncertainty about future projections in the actual or desired levels of public spending, the future returns on public sector capital or the future interest on public debt and to allow for more general data generating processes for national income and the tax base. It is then prudent to budget for slightly higher levels of future government spending and the market rate of interest and for slightly lower levels of future financial returns on public sector 
capital than the mathematically expected levels. ${ }^{10}$ Again, the minister of finance on average enjoys less ambitious spending desires and higher returns on public sector assets than budgeted as well as windfall revenues as time proceeds and is thus able to gradually cut debt service and the tax rate and increase the level of public consumption and public investment. Another extension is to introduce quadratic costs of adjustment for the stock of public sector capital or the level of government spending. One can also allow for adverse effects of the tax rate on the tax base. The marginal cost of taxation is then likely to increase in recessions and fall during booms. This strengthens the case for a prudent counter-cyclical policy. Also, the structural unemployment rate may be positively affected by taxation. This also strengthens the case for such a prudent policy, because one does not want to increase tax rates in a recession as this would increase unemployment even further.

Prudence favors accumulation of assets to cope with future risk, but then it is optimal to spend less on actions to prevent risk with adverse consequences (e.g., Eeckhoudt and Gollier 2005). Similarly, a prudent minister of finance who has accumulated a big buffer is less likely to take actions to prevent the tax base from shrinking and is more likely to dish out favors towards election eve. It is therefore interesting to further develop the rationale for a strong and prudent minister of finance within the context of a political business cycle framework with finite election horizons. In practice, newly elected governments adopt a finite horizon, typically the period to the next election, and set themselves a target for the final financial deficit or surplus. ${ }^{11}$ The key question is how prudent and strong a finance minister should be to find an optimal trade-off between the common-pool distortions in fragmented governments and short-run election motives. If the electorate 'forgets' quickly, the adverse welfare effects of short-run political manipulation dominate the beneficial welfare effects of offsetting the intertemporal biases of the common-pool problem. Hence, if the electorate can be wooed by results on election eve, a less prudent policy is needed to offset the intertemporal distortions of squabbling spending ministers.

Acknowledgements This paper is inspired by my former cabinet colleague Gerrit Zalm, who was Minister of Finance during 1994-2007 and initiator of the concept of prudent budgetary policy in the Netherlands. It is also a requiem, since the new administration has abandoned this policy. I thank Torsten Anderson, Henning Bohn, Lans Bovenberg, Robert Dur, Ferd Crone, Bas Jacobs, Mark Roscam Abbing, Steven Poelhekke, Paul Tang, Sweder van Wijnbergen, participants of the 2007 Public Sector Economics CESifo Area Conference, two anonymous referees and the editor Jay Wilson for helpful comments on an earlier version.

Open Access This article is distributed under the terms of the Creative Commons Attribution Noncommercial License which permits any noncommercial use, distribution, and reproduction in any medium, provided the original author(s) and source are credited.

\footnotetext{
${ }^{10}$ In general equilibrium models with incomplete markets, the government also builds a war chest of assets as a precaution against the unpredictable necessities of war (Aiyagari et al. 2002).

${ }^{11} \mathrm{~A}$ lax final target combined with prudent budgeting may then even be less cautious than an ambitious final target combined with realistic budgeting.
} 


\section{Appendix}

With some rudimentary micro foundations, one can justify this welfare criterion. With output in the first period being set to 1 and in the second period to $1+\varepsilon$, the goods market equilibrium conditions in the two periods are $c_{1}+g_{1}=1-\phi \tau_{1}^{2}$ and $c_{2}+g_{2}=1+\varepsilon-\phi \tau_{2}^{2}$, where $c_{t}$ denotes private consumption in period $t$ and the parameter $\phi$ defines the magnitude of the tax collection costs. If felicity in each period is given by $\left[c_{t}-\frac{1}{2} \chi \phi\left(\hat{g}^{*}-g_{t}^{2}\right)\right] / \phi$, we obtain (2) with $\hat{g}=\hat{g}^{*}+(\phi \chi)^{-1}$. Hence, the bliss level of public spending is adjusted upwards somewhat. The household budget constraints $c_{1}=1-\tau_{1}-d-\frac{1}{2} \phi \tau_{1}^{2}$ and $c_{2}=1-\tau_{2}(1+\varepsilon)+d-\frac{1}{2} \phi \tau_{2}^{2}$ are automatically satisfied due to Walras's law, so that $d$ also indicates private saving. The household and government budget constraints use the first-order Taylor series approximation $\tau_{2}(1+\varepsilon) \cong \tau_{2}+\bar{\tau} \varepsilon$, where $\bar{\tau}>0$ is the value of the second-period tax rate around which the budget constraints are linearized.

\section{References}

Aiyagari, R. (1995). Optimal capital income taxation with incomplete markets, borrowing constraints, and constant discounting. Journal of Political Economy, 103(6), 1158-1175.

Aiyagari, R., \& McGrattan, E. R. (1998). The optimum quantity of debt. Journal of Monetary Economics, 42, 447-469.

Aiyagari, R., Marcet, A., Sargent, T. J., \& Seppälä, J. (2002). Optimal taxation without state-contingent debt. Journal of Political Economy, 110(6), 1220-1254.

Alesina, A., \& Tabellini, G. (1990). A positive theory of fiscal deficits and government debt. Review of Economic Studies, 57(3), 403-414.

Barro, R. J. (1979). On the determination of the public debt. Journal of Political Economy, 87(5), 940-971.

Beetsma, R., \& van Wijnbergen, S. (2007). Zalm-norm geen zegen maar bron van instabiliteit. Trouw, 14 March.

Bommier, A. (2006). Uncertain lifetime and intertemporal choice: risk aversion as a rationale for time discounting. International Economic Review, 47(4), 1223-1246.

Bommier, A., \& Rochet, J.-C. (2006). Risk aversion and planning horizons. Journal of the European Economic Association, 4(4), 708-734.

Chari, V. V., Christiano, L. J., \& Kehoe, P. J. (1994). Optimal fiscal policy in a business cycle model. Journal of Political Economy, 102(4), 617-652.

Drazen, A. (2000). The political business cycle after twenty five years (Mimeograph). University of Maryland and Hebrew University of Jerusalem.

Eeckhoudt, L., \& Gollier, C. (2005). The impact of prudence on optimal prevention. Economic Theory, 26, 989-994.

Hallerberg, M., \& von Hagen, J. (1997). Electoral institutions, cabinet negotiations, and budget deficits in the European Union (Working Paper No. 6341). NBER, Cambridge, MA.

Jacobs, B. (2007). De Zalmnorm en het begrotingsbeleid 1994-2007. Tijdschrift voor Openbare Financiën, 1.

Kimball, M. S. (1990). Precautionary saving in the small and in the large. Econometrica, 58, 53-73.

Nordhaus, W. D. (1975). The political business cycle. Review of Economic Studies, 42, 169-190.

Persson, T., \& Svensson, L. E. O. (1989). Why a stubborn conservative would run a deficit: policy with time-inconsistent preferences. Quarterly Journal of Economics, 104(2), 325-345.

Persson, T., \& Tabellini, G. (2000). Political economics. Explaining economic policy. Cambridge: MIT Press.

Rogoff, K. (1985). The optimal degree of commitment to an intermediate monetary target. Quarterly Journal of Economics, 100, 1169-1189.

Rogoff, K. (1990). Equilibrium political budget cycles. American Economic Review, 80, 21-36.

Shin, Y. (2006). Ramsey meets Bewley: optimal government financing with incomplete markets (Mimeograph). University of Wisconsin-Madison. 
Sibley, D. S. Permanent and transitory effects of optimal consumption with wage income uncertainty, Journal of Economic Theory, 68-82 (1975).

Swank, O. H. (2002). Budgetary devices for curbing spending prone ministers and bureaucrats. Public Choice, 111, 237-257.

Velasco, A. (2000). Debts and deficits with fragmented fiscal policymaking. Journal of Public Economics, 76(1), 105-125.

van der Ploeg, F. (1993). A closed-form solution for a model of precautionary saving. Review of Economic Studies, 60(2), 385-396.

van der Ploeg, F. (2007). Prudent budgetary policy_Political economy of precautionary taxation (Working Paper No. 1973). CESifo, Munich.

Von Hagen, J., \& Harden, I. J. (1995). Budget processes and commitment to fiscal discipline. European Economic Review, 39, 771-779.

Whittle, P. (1990). Risk-sensitive optimal control. Chichester: Wiley.

Zeldes, S. P. (1989). Optimal consumption with stochastic income: deviations from certainty equivalence. Quarterly Journal of Economics, 104(2), 275-298. 